\title{
Physicochemical, primary production and trophic state variation of an urban artificial water body located in the central zone of the tropical latitude of Mexico
}

\begin{abstract}
Artificial water bodies at tropical latitudes have regular or extreme water contributions dependent of climate and interannual variations that result in differences in the physicochemical characteristics of the water; in addition to the climate. They receive peripheral runoff two, according to geomorphology; in the case of Mexican artificial water bodies as Cantera Oriente, they will also depend on the orography that entails changes in the volumes of water. All of this influence in conservative and non-conservative physiochemical components through dilute the water in the rainy season and concentrate it in the dry season. Therefore, this paper estimates the variations of: temperature, conductivity, dissolved oxygen, $\mathrm{pH}$, with nutrients (total phosphorus and nitrogen, chlorophyll "a" and primary production). In the Cantera Oriente all this parameters resulting in an oxic and anoxic condition, as well as a widely variable hypertrophy, depending on the month of year, in addition, anthropogenic sewage runoff must be added.
\end{abstract}

Volume 5 Issue 2 - 202I

\author{
Guadalupe de la Lanza Espino, Salvador \\ Hernández Pulido,Angel D Ceballos Ramirez \\ Institute of Biology, Department of Zoology, UNAM, Mexico
}

Correspondence: Guadalupe de la Lanza Espino, Department of Zoology, Institute of Biology, Universidad Nacional Autonoma de Mexico, Third Exterior Circuit, Botanical Garden, Ciudad Universitaria, Mexico, DFCP 04510, Mexico, Tel 5556229132, Fax 5555500I64,Email gdlle@unam.mx,gdlle@ib.unam.mx

Received: March 02, 202I | Published: April 01, 2021

Keywords: artificial water ponds, Mexico

\section{Introduction}

Both natural and artificial bodies of water can have different uses, for example, natural ones are used mainly in anthropogenic activities such as agriculture, industry and human consumption; but in the case of artificial or man-made ones, they are also used for recreation and in some cases as reservoirs or reservoirs regulating the volume of water. It should be noted that both receive water or runoff from the basin in which they are located, as well as wastewater of different quality and magnitude, altering their physicochemical depending on the runoff adjacent to the reservoir. In the southern portion of the Valle de México basin (Mexico City) at an altitude of approximately $2400 \mathrm{~m}$ National Research Council, ${ }^{1}$ there are some artificial bodies of water that have been studied by different authors from different points of view; Among the aforementioned artificial bodies are: La Cantera Oriente, Bosque de Aragón, de Chapultepec, Parque de Tezozomoc, Lake Nabor Carrillo and the dams of the State of Mexico, among others, each with distinctive geomorphological and physicochemical characteristics but with levels of eutrophication. even hypereutrophication according to the trophic state index proposed by Carlson ${ }^{2}$ using the concentrations of chlorophyll "a", phosphorus and the transparency to the Secchi disk. González-Gutiérrez; SantiagoLima, ${ }^{3,4}$ used to estimate the seasonal variation of various groups of zooplankton and its relationship with the trophic state.

Most of the works refer to physicochemical records and the trophic state of the water in a specific way or associating them with organisms and their life cycles, without highlighting the spatial and temporal variation of the environmental factors that determine wide fluctuations. The first studies were carried out in the Oriente Quarry and published in an Illustrated Guide, Lot, ${ }^{5}$ including a geological and biological characterization (algae, protozoa, arthropods, fish, amphibians, reptiles and birds) also, of the lake landscape; It stands out the inclusion of some physicochemical parameters of specific sites (North, South and the Canal) that were averaged, whose results showed that the levels of total phosphorus and nitrogen indicated that the water showed a significant hyper-eutrophication. Given the above, the present work aims to determine in the East Quarry the conservative and non-conservative physicochemical parameters, the primary production and the trophic state in sites with different spatial characteristics (geomorphology) and their temporal variation (in four seasons of the year).

\section{Study area}

The East Quarry is a buffer zone; Although it is located outside the university campus, it is considered as part of the University's Ecological Reserve and is of great importance for the Basin of Mexico since it has the presence of aquatic environments and a refuge from the biota. According to information from Lot and Cano Santana ${ }^{6}$ some of the following characteristics are summarized. It is located between the geographical coordinates $19^{\circ} 18^{\prime} 21^{\prime \prime}-19^{\circ} 20^{\prime} 11$ ' North and 99 $\circ 10^{\prime} 15^{\prime \prime}-99^{\circ} 12^{\prime} 4^{\prime \prime}$ 'West. It is located 2,270 to 2,349 meters above sea level.

It currently has an area of 237.33 hectares, comprising three core zones and 13 buffer zones. The climate is temperate subhumid with rains in summer [Cb (w1) w], with a rainy season from June to October and a dry season from November to May. The annual average temperature is $15.6{ }^{\circ} \mathrm{C}$; Topographically, the Ecological Reserve is located between the isotherms of $15.3{ }^{\circ} \mathrm{C}$ and $15.6{ }^{\circ} \mathrm{C}$. The mean annual rainfall is $833 \mathrm{~mm}$ according to Lot and Cano Santana. ${ }^{6}$ To manage the information in the present study, the East Quarry was divided into sections (North, Center and South sites). Six bimonthly departures were made to the Oriente Quarry, in August, October and December 2017, as well as in March and June 2018, trying to have seasonal information. Eight sampling sites were chosen based on geomorphology Figure 1. 


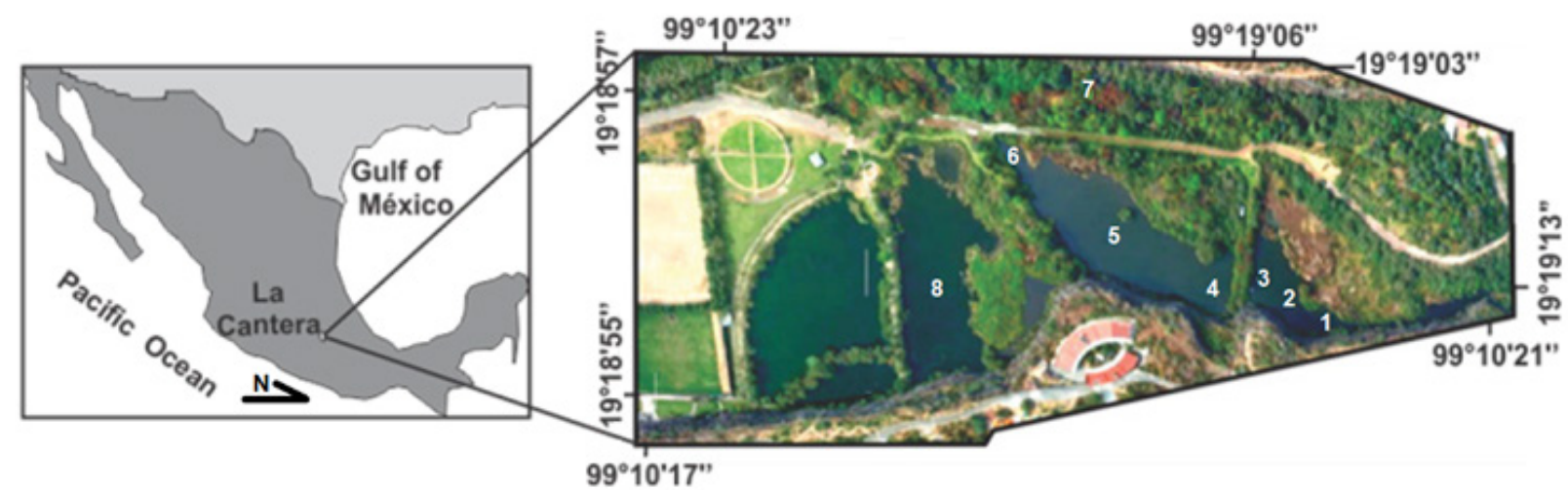

Figure I Aerial map of the Oriente Quarry with the stations marked. North Section sites I to 3; Center section sites 4 to 6; Spring site 7; South section site 8.

\section{Methodology}

Temperature $\left({ }^{\circ} \mathrm{C}\right)$, conductivity $(\mu \mathrm{S})$, dissolved oxygen $(\mathrm{mg} / \mathrm{L})$, its saturation percentage and $\mathrm{pH}$ were measured in situ and at half a column of water, using the YSI 556 MPS multiparametric probe. At that depth, water samples were taken with a Van Dorn bottle that were transferred to properly labeled one-liter bottles, which were frozen after collection for the determination of nutrients. In addition, for the quantification of chlorophyll "a", $250 \mathrm{~mL}$ of water was filtered through a $0.45 \mu \mathrm{m}$ millipore filter that was frozen until its subsequent analysis in the laboratory. In the water samples, nitrates, nitrites, ammonium, orthophosphates, total phosphorus and nitrogen were determined using spectrophotometric techniques with the Hach DR 890 equipment based on APHA techniques; ${ }^{7}$ the quantification of the Chemical Oxygen Demand (COD) was through titration and finally the chlorophyll "a" by means of an acetone extraction and its APHA spectrophotometric quantification. ${ }^{7}$ In the case of the assessment of the trophic state of the East Quarry, the Carlson formulas (2) were used, which are based on the concentration of total phosphorus $(\mu \mathrm{g} / \mathrm{L})$ and chlorophyll "a" $\left(\mathrm{mg} / \mathrm{m}^{3}\right)$; in addition to the one proposed by Vollenweider et $a .^{8}$ which uses the logarithms of the content of chlorophyll "a", total phosphorus and nitrogen, together with the absolute value of the deviation of the percentage of oxygen saturation.

Carlson Trophic State Index (2).

$\operatorname{IET}(\mathrm{Cl}-\mathrm{a})=10(6-(2.04-0.68 \ln \mathrm{Cl}-\mathrm{a} / \ln 2))$; where $\mathrm{Cl}-\mathrm{a}=$ chlorophyll a concentration in $\mathrm{mg} / \mathrm{m}^{3}$; IET $(\mathrm{FT})=14.42 \mathrm{ln} \mathrm{FT}+4.15$; where $\mathrm{FT}=$ total phosphorus concentration in $\mu \mathrm{g} / \mathrm{L}$.

Vollenweider index (8).

TRIX $=(\log 10(\mathrm{Cl}-\mathrm{a} \times \mathrm{aD} \% 0 \times \mathrm{NT} \times \mathrm{FT})+\mathrm{k}) / \mathrm{m}$; where $\mathrm{Cl}$ $\mathrm{a}=$ chlorophyll a concentration in $\mathrm{mg} / \mathrm{m} 3 ; \mathrm{D} \% 0=$ absolute value of the deviation of the oxygen saturation percentage, that is $100-\%$ $\mathrm{DO} \mid$; NT=total nitrogen concentration in $\mu \mathrm{g} / \mathrm{L}$; FT=total phosphorus concentration in $\mu \mathrm{g} / \mathrm{L} ; \mathrm{K}=1.5$ and $\mathrm{M}=1.2$ Constant values to adjust the index scale.

\section{Statistical analysis}

In addition to performing the physicochemical behavior under environmental scientific knowledge, a PERMANOVA multivariate analysis was performed to determine differences between seasons of the year and the different sections of the Oriente Quarry, using the PAST 3.20 program. The spatial-temporal evaluation of the environmental dynamics at the study site was approached as a factorial design with fixed effects: epochs and sections. Likewise, multivariate analyzes and a canonical correlation analysis were carried out to determine differences between the physicochemical parameters (temperature, conductivity, dissolved oxygen, nutrients and chlorophyll) given the seasonal fluctuations based on the rainy and dry seasons, that is, during the summer. (August), autumn (October), winter (December and February) and spring (April and June) and the different sections (North, Center, South and Spring) of the East Quarry using the SPSS 20.0 program and Past 30.2 according to Hammer et al. ${ }^{9}$

\section{Results}

\section{Temperature}

This parameter fundamentally varied temporarily. The maximum temperatures were recorded in June and the minimum in December. The widest range of 19.4 to $15.9{ }^{\circ} \mathrm{C}$ was recorded in April and the narrowest of 16.3 to $17.6{ }^{\circ} \mathrm{C}$ in August. Spatially, in the Spring a greater homogeneity was determined throughout the study with a thermal variation of $0.8^{\circ} \mathrm{C}$ Figure 2(A).

\section{Conductivity}

The conductivity showed a wide variation both temporal and spatial, with an approximately similar interval between 404 and 528 $\mu \mathrm{S} / \mathrm{cm}$; in the Spring it varied from 395 to $500 \mu \mathrm{S} / \mathrm{cm}$ Figure 2(B).

\section{Total hardness $\mathrm{CaCO}_{3}$}

According to the classification proposed by de la Lanza ${ }^{10}$ the hardness levels characterized the water from the Oriente Quarry from soft to moderately hard; Despite the above, in April in the North section (channel) they were characterized as hard waters Figure 2(C).

\section{pH}

The interval of this parameter was of little spatial and temporal variation, with levels mostly tending towards neutral and exceptionally some slightly acid punctual records, as in June from 5.5 to 7.1 Figure 2(D).

\section{Dissolved oxygen and saturation}

The oxygen concentration showed a wide variation both temporal and spatial. The widest oscillation from 5.5 to $13.9 \mathrm{mg} / \mathrm{L}$ was registered in August where the highest percentage saturation intervals were from 81.3 to $177.7 \%$, similar to what was registered in June with an interval from 92.4 to $112 \%$ except for the Manantial site with $60 \%$, both samplings coinciding with the rainy season Figure 3(A \& B). 

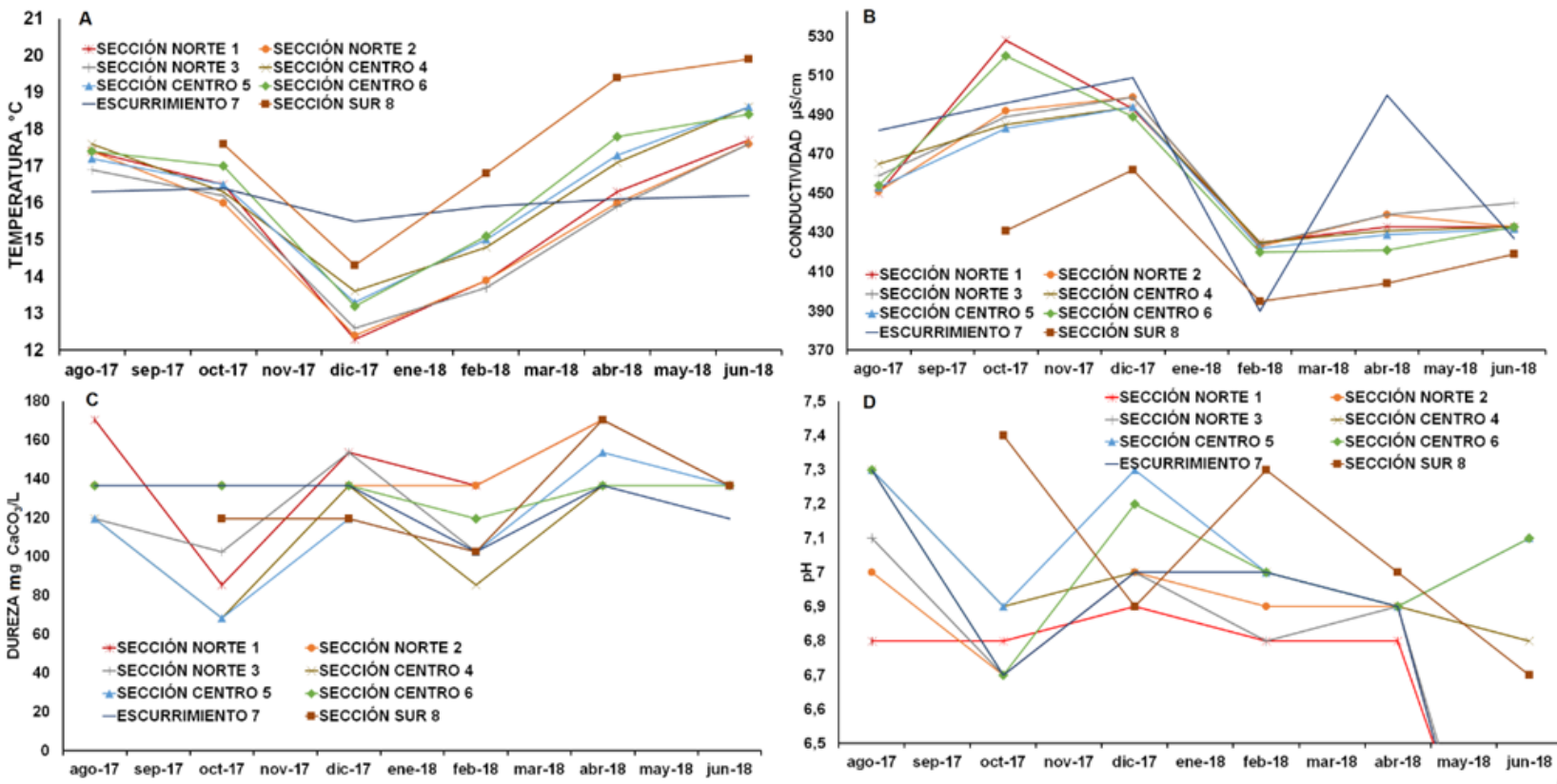

Figure 2 Spatial-temporal variation of Temperature (A), Conductivity (B), Hardness (C) and pH (D), in the Oriente Quarry, Mexico.

\section{Nutrients}

\section{Ammonium}

Ammonium levels were heterogeneous spatiotemporally, registering the widest range from 12.1 to $24.2 \mu \mathrm{M}$ in February and the narrowest from 22.1 to $26.4 \mu \mathrm{M}$ in June; It should be noted that contents close to the maximum were determined throughout the Oriente Quarry in that month and in October Figure 3(C).

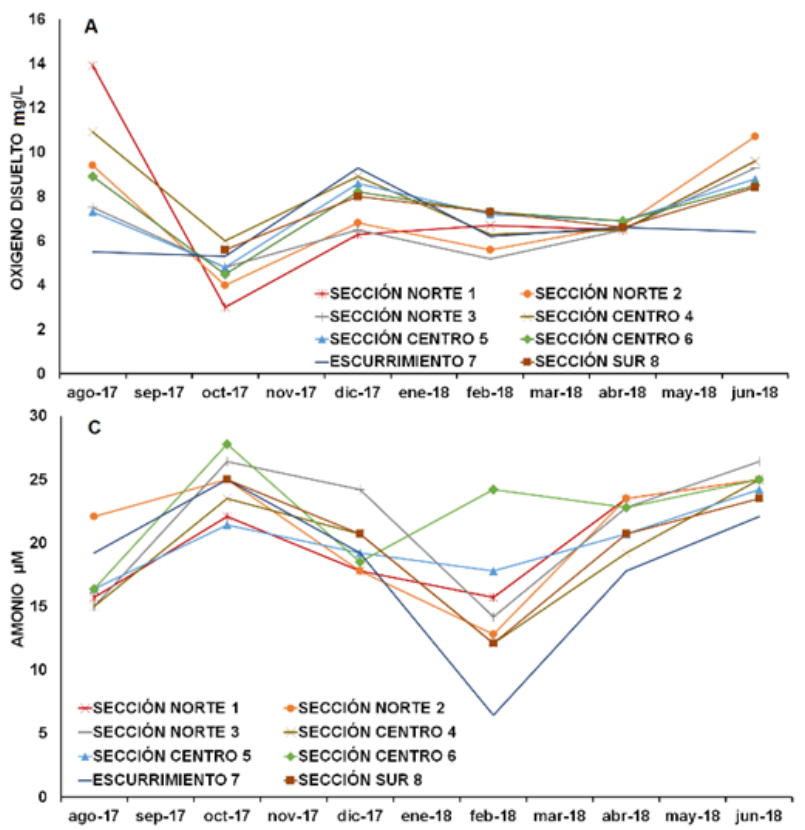

\section{Nitrates}

Nitrates had a temporal interval of 37.8 to $39.2 \mu \mathrm{M}$ in April and the broadest one from 17.1 to $57.1 \mu \mathrm{M}$ in June, the latter concentration for the North and Central sections Figure 3(D).

\section{Nitrite}

Nitrite concentration was temporally and spatially heterogeneous. The widest range of 0.2 to $7.3 \mu \mathrm{M}$ was recorded in June Figure 4(A).

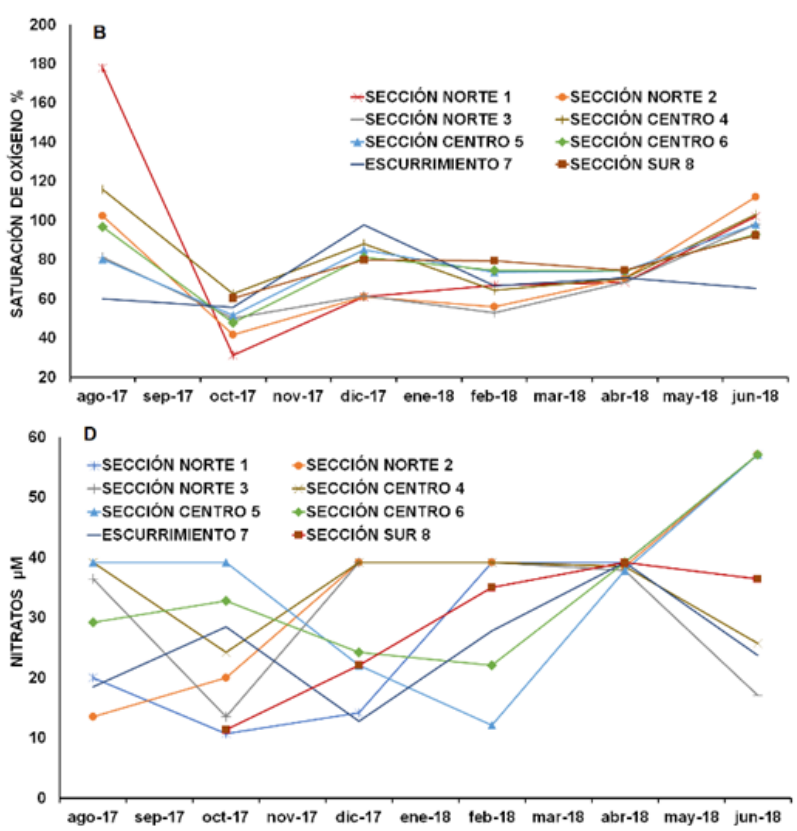

Figure 3 Spatio-temporal variation of Dissolved Oxygen (A), Oxygen Saturation (B), Ammonium (C) and Nitrates (D), in the Oriente Quarry, Mexico.

\section{Total nitrogen}

Total nitrogen concentration was heterogeneous and with a wide range, from $257 \mu \mathrm{M}$ to $835 \mu \mathrm{M}$ in August and February respectively, in the Central section Figure 4(B).

\section{Orthophosphates}

The orthophosphate concentrations were heterogeneous, registering contents close to $20 \mu \mathrm{M}$; August stood out with the interval from 21.2 to $38.7 \mu \mathrm{M}$ and June with the widest interval from 24.5 to

Citation: Espino GL, Pulido SH, Ramirez ADC. Physicochemical, primary production and trophic state variation of an urban artificial water body located in the central zone of the tropical latitude of Mexico. Int J Hydro. 202।;5(2):46-56. DOI: I0.I5406/ijh.202I.05.00265 
$83.8 \mu \mathrm{M}$ at the Manantial site. The lowest levels between 10.3 and $12.5 \mu \mathrm{M}$ were in October, December and February, in the South zone "Club Lake" (site 8), which is the area where the influence of the discharges from the toilets used by the athletes of the University club is likely; however, they increased to $35.8 \mu \mathrm{M}$ in June 2018, which could be a result of the increase in sports training Figure $4(C)$.

\section{Total match}

Total phosphorus levels were temporally and spatially heterogeneous, however, an increase was observed in April 2018 from 110.9 to $133.5 \mu \mathrm{M}$. The widest range from 65.1 to $141.9 \mu \mathrm{M}$ was recorded in August. In general, in February and April (dry months) the levels of total phosphorus increased in all the sampling sites, with contents up to $133.5 \mu \mathrm{M}$ Figure 4(D).

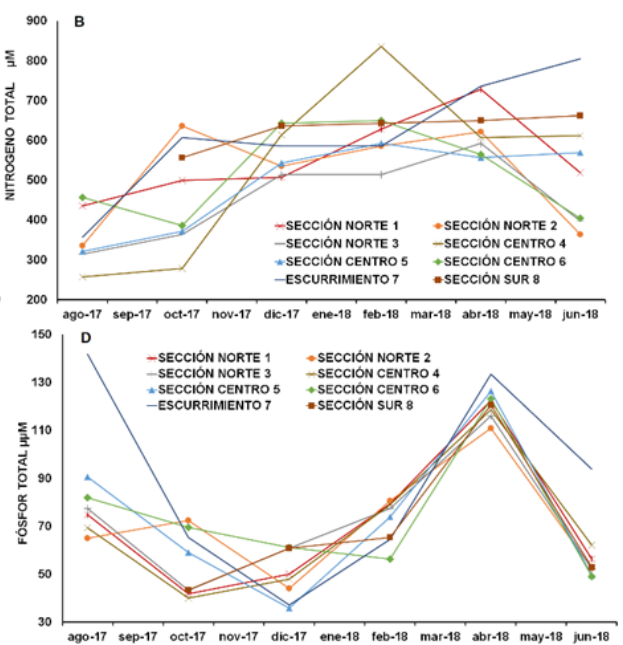

Figure 4 Spatio-temporal variation of Nitrites (A),Total Nitrogen (B), Orthophosphates (C) and Total Phosphorus (D), in the Oriente Quarry, Mexico.

\section{Chemical oxygen demand (COD)}

The COD showed a wide variation interval, with the highest contents in February and April; At site 8, the South section, there was an increase in the last three samplings of 2018 , reaching maximum levels of up to $92 \mathrm{mg} / \mathrm{L}$. Comparatively, the months of August, October and December of 2017 stood out for their lowest levels that ranged between 27 and $46 \mathrm{mg} / \mathrm{L}$, which could be associated with the rainy season; Figure 5(A).

\section{Chlorophyll "to"}

Chlorophyll concentrations varied widely in all samplings, with the lowest levels in October and the highest in February and April 2018; however, at site 7 called El Manantial, which is located at the foot of the rocky wall, and whose water comes from the infiltrations of Cerro Ajusco, with the lowest contents of $2.9-12.3 \mathrm{mg} / \mathrm{L}$. The maximum chlorophyll recorded was $543.9 \mathrm{mg} / \mathrm{m}^{3}$ at site three of the northern section that corresponds to the mouth of the Canal in August Figure 5(B).

\section{Primary production}

With the formula proposed by Ryther et al., ${ }^{11}$ and the modifications made by Lara-Lara and Álvarez-Borrego ${ }^{12}$ both temporal and spatial heterogeneous productions were estimated, with an increase in most of the sites, mainly in February. April and June. The variation interval for all the sites was approximately $200 \mathrm{mg} / \mathrm{m} 3$ / h, highlighting site seven (Manantial) for the lowest productivity, for the same location reason already indicated Figure 5(C).

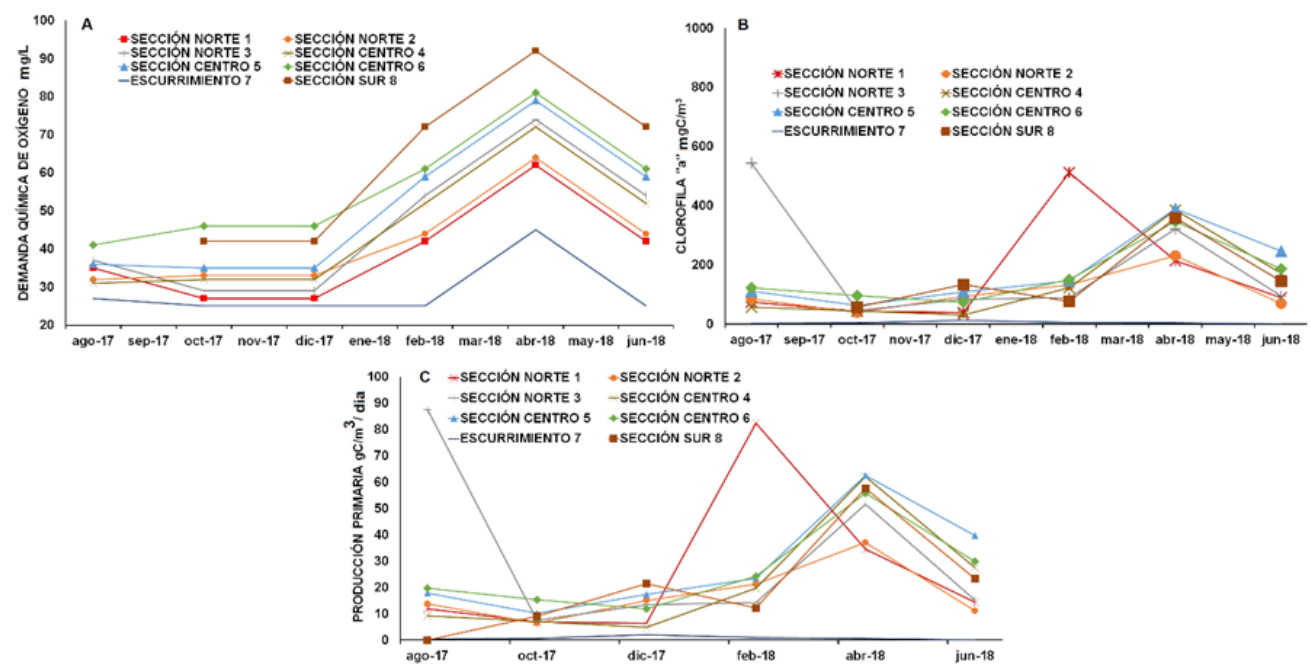

Figure 5 Spatio-temporal variation of Chemical Oxygen Demand (A), Chlorophyll (B) and Primary Production (C), in the Oriente Quarry, Mexico.

Citation: Espino GL, Pulido SH, Ramirez ADC. Physicochemical, primary production and trophic state variation of an urban artificial water body located in the central zone of the tropical latitude of Mexico. Int J Hydro. 202I;5(2):46-56. DOI: I0.15406/ijh.202I.05.00265 


\section{Trophic state estimation}

\section{Carlson index}

Based on the proposal by Carlson ${ }^{2}$ a state between eutrophic to hypertrophic was estimated. Sites one, two, three, four, five, six and eight presented levels above 80 units, indicating a state of hypertrophy throughout the year, with values above the limit of the index $($ IET $>100)$ in all these sites in the month of April, except for site two. The Manantial station (site 7) stands out for presenting lower values due to its location already indicated, fluctuating between 63 and 83 units, which characterizes it as eutrophic (Table 1).

Table I Trophic condition according to the Carlson Index 2

\begin{tabular}{lllllll}
\hline Station & I7-Aug & 17-Oct & 17-Dec & 18-Feb & 18-Apr & 18-Jun \\
\hline 1 & 94 & 87 & 88 & 104 & 103 & 93 \\
two & 93 & 91 & 91 & 97 & 83 & 91 \\
3 & 104 & 88 & 93 & 95 & 104 & 92 \\
4 & 92 & 87 & 86 & 97 & 105 & 97 \\
5 & 97 & 91 & 90 & 97 & 106 & 96 \\
6 & 97 & 95 & 92 & 95 & 105 & 95 \\
7 & 83 & 79 & 80 & 77 & 83 & 63 \\
8 & & 89 & 95 & 93 & 105 & 95 \\
\hline
\end{tabular}

\section{Trix index}

Using the formulas proposed by Vollenweider et al. ${ }^{8}$ the results obtained characterize the Oriente Quarry as a hypereutrophic system, with values between 7.96 and more than 10 , above the calculable maximum. It should be noted that approximately $46 \%$ of the sites sampled throughout the year registered indices above the maximum index, given the high concentrations of total phosphorus, total nitrogen and chlorophyll "a". According to Muciño-Márquez et al. ${ }^{13}$ an index between 6 and 10 units is indicative of a system with poor quality and highly productive water (Table 2 ).

Table 2 TRIX index calculated using the formula proposed by Wollenweider et al. ${ }^{8}$

\begin{tabular}{lllllll}
\hline Station & I7-Aug & 17-Oct & I7-Dec & I8-Feb & I8-Apr & I8-Jun \\
\hline I & 10.1 & 9.9 & 9.7 & 10.8 & 10.7 & 9 \\
two & 8.9 & 10.1 & 10 & 10.4 & 10.6 & 9.4 \\
3 & 10.4 & 9.7 & 10.1 & 10.2 & 10.8 & 8.9 \\
4 & 10.4 & 9.7 & 10.1 & 10.2 & 10.8 & 9.5 \\
5 & 9.9 & 9.9 & 9.6 & 10.3 & 10.8 & 9.4 \\
6 & 9.4 & 10.2 & 9.8 & 10.2 & 10.7 & 9.6 \\
7 & 9 & 9.1 & 8.2 & 9.1 & 9.2 & 7.9 \\
8 & & 9.8 & 10.1 & 9.9 & 10.8 & 9.7 \\
\hline
\end{tabular}

\section{Statistical analysis}

PERMANOVA multivariate analyzes were performed in order to determine significant differences between the different sections of the Oriente Quarry and between the six months of the year studied.

\section{Spatial variation}

The multivariate PERMANOVA test determined significant differences between the different sections of the Oriente Quarry with a $\mathrm{p}<0.0001$. The post-hoc analysis found statistically significant differences between the Spring and all the sections of the East Quarry, and between the North section and the South section (Table 3). The PERMANOVA test was also carried out, which found significant differences between the different times of the year, according to the annual climatic variation indicated by García ${ }^{14}$ with a $p=0.0025$. The post-hoc test characterized significant differences between spring and fall, fall and winter, and fall with summer. The analysis found no differences between winter and summer, as well as spring and winter (Table 4).

Table 3 Results of the post-hoc analysis of the PERMANOVA multiparametric test between the different sections of the Oriente Quarry

\begin{tabular}{lllll}
\hline & North Section & Center Section & Spring & South Section \\
\hline North Section & & & \\
Center Section & 0.5293 & & \\
Spring & 0.0001 & 0.0001 & \\
South Section & 0.025 & 0.071 & 0.002 \\
\hline
\end{tabular}

Citation: Espino GL, Pulido SH, Ramirez ADC. Physicochemical, primary production and trophic state variation of an urban artificial water body located in the central zone of the tropical latitude of Mexico. Int J Hydro. 202I;5(2):46-56. DOI: I0.I5406/ijh.202I.05.00265 
Table 4 Results of the post-hoc analysis of the PERMANOVA multiparametric test between the different seasons of the year according to the annual climatic variation referred to by García ${ }^{14}$

\begin{tabular}{lllll}
\hline & Summer & Fall & Winter & Spring \\
\hline Summer & & & \\
Fall & 0.0444 & & \\
Winter & 0.3612 & 0.0075 & \\
Spring & 0.0592 & 0.0004 & 0.1515 \\
\hline
\end{tabular}

\section{Multivariate analysis and canonical correlation}

Three multivariate analyzes were carried out in the discriminant modality, in order to contrast the possible influence of the site and the sampling month, as well as the season of the year on the parameters measured. Figure 6 shows the multivariate means of these analyzes, where a clear temporal separation is observed between the sampling months (the most divergent months being June and December, Figure 6(A), these being regrouped as seasons: low water, warm Transitional and cold rains show complete discrimination, indicating their temporal separation Figure 6(B) and for the case of the spatial component, the North section and the Spring, behaved differently and the other sections share affinity Figure 6(C). On the other hand, the values of the "F" test and the level of significance (p) of the measured variables are shown, in relation to the comparisons between months, sections and seasons, among which conductivity, dissolved oxygen stand out. , COD and total phosphorus as they are variables that have a highly significant influence on the spatio-temporal dynamics of the Oriente Quarry (Table 5).
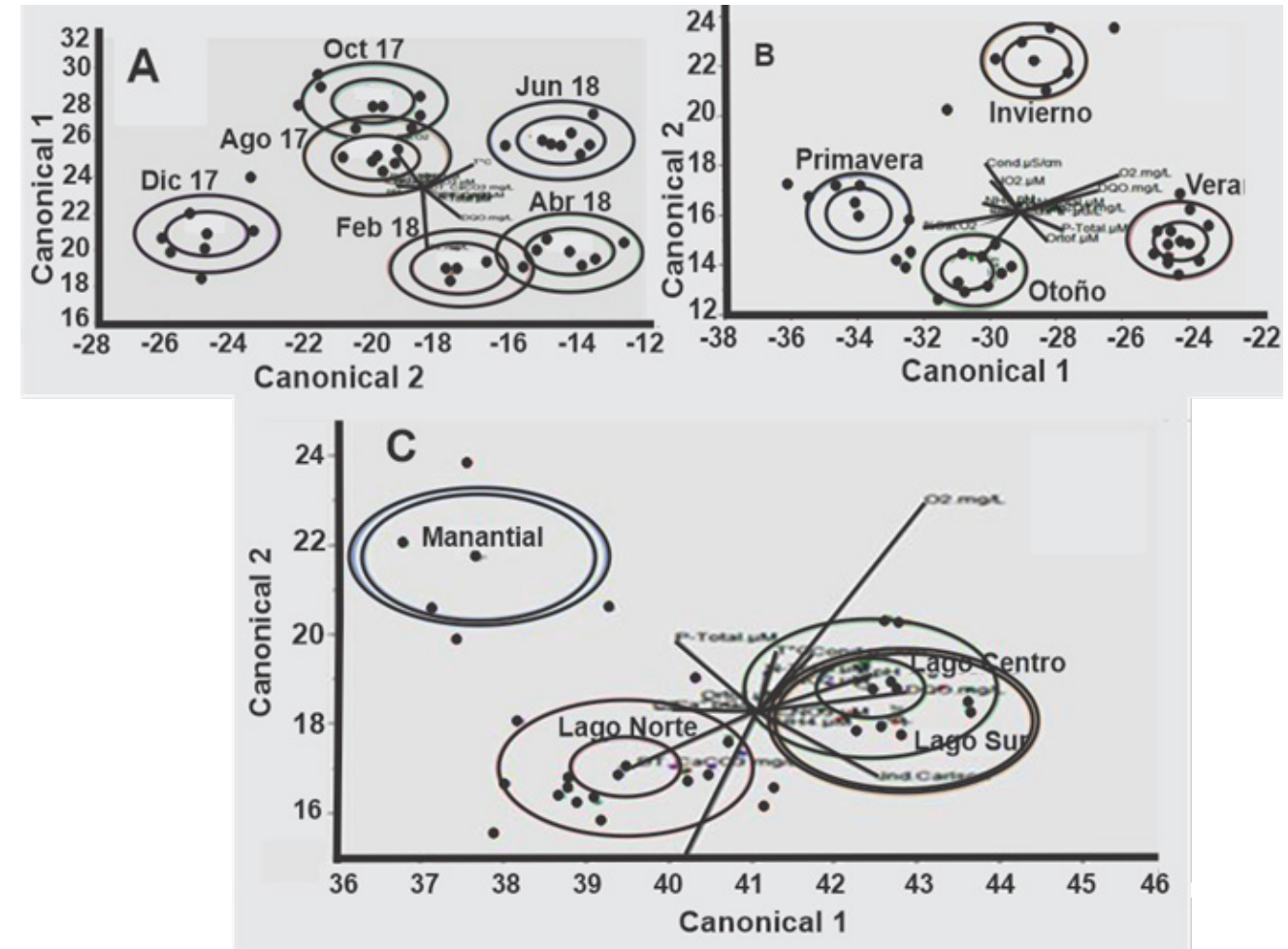

Figure 6 (A, B \& C) Multivariate means (canonical) of the temporal comparison: months-epochs (A, B) and the spatial variation (C) based on physicochemical indicators and their corresponding trophic states of the aquatic system of the East Quarry, CU.

Table 5 Physicochemical and biotic indicators that were significant in the discriminant multivariate analyzes (months, epochs and sections) of the aquatic system of Cantera Oriente, Ciudad Universitaria. Those variables with statistically significant differences according to months, sections or seasons are highlighted in red. Statistically significant variables in two or more contrasts are highlighted in bold

\begin{tabular}{lllllll}
\hline Contrast & Months & \multicolumn{3}{l}{ Sections } & Times \\
\hline Variable & F & P value & F & P value & F & P value \\
\hline $\mathrm{T}^{\circ} \mathrm{C}$ & 21,439 & 0 & 0.164 & 0.91 & 16,147 & 0 \\
Conductivity & 11.64 & 0 & 2,588 & 0.07 & 13,395 & 0 \\
Total hardness & 1,025 & 0.42 & 7,453 & 0 & 0.413 & 0.74 \\
$\mathrm{pH}$ & 6,859 & 0 & 6,195 & 0.001 & 0.388 & 0.76 \\
$\mathrm{O} 2$ & 5,081 & 0.001 & 4,600 & 0.008 & 6,116 & 0.002 \\
$\%$ saturation $\mathrm{O}_{2}$ & 2,906 & 0.03 & 0.422 & 0.73 & 3,285 & 0.03 \\
$\mathrm{COD}$ & 8,978 & 0 & 4,886 & 0.006 & 11,857 & 0 \\
\hline
\end{tabular}

Citation: Espino GL, Pulido SH, Ramirez ADC. Physicochemical, primary production and trophic state variation of an urban artificial water body located in the central zone of the tropical latitude of Mexico. Int J Hydro. 202I;5(2):46-56. DOI: I0.I5406/ijh.202I.05.00265 


\begin{tabular}{|c|c|c|c|c|c|c|}
\hline \multirow{2}{*}{\begin{tabular}{|l|} 
Contrast \\
Variable
\end{tabular}} & \multicolumn{2}{|l|}{ Months } & \multicolumn{2}{|c|}{ Sections } & \multicolumn{2}{|c|}{ Times } \\
\hline & $\mathbf{F}$ & P value & $\mathbf{F}$ & $P$ value & $\mathbf{F}$ & $P$ value \\
\hline Orthophosphates & 6,594 & 0 & 2,103 & 0.12 & 4,833 & 0.008 \\
\hline Total Phosphorus & 21,837 & 0 & 7,007 & 0 & 5,237 & 0.006 \\
\hline $\mathrm{NH} 4$ & I,799 & 0.14 & 0.569 & 0.63 & 1,630 & 0.2 \\
\hline $\mathrm{NO} 2$ & 3,213 & 0.02 & 2,254 & 0.1 & 4,018 & 0.01 \\
\hline $\mathrm{NO} 3$ & 1,062 & 0.4 & 0.874 & 0.46 & 0.341 & 0.79 \\
\hline Total Nitrogen & 4,142 & 0.006 & $\mid, 091$ & 0.36 & 2,863 & 0.05 \\
\hline Chlorophyll & 0.721 & 0.61 & 1,463 & 0.24 & 0.452 & 0.71 \\
\hline Carlson Index & $\mathbf{1}, 755$ & 0.15 & 7,480 & 0 & 1,292 & 0.29 \\
\hline
\end{tabular}

\section{Discussion}

The thermal behavior of the Oriente Quarry showed little seasonal variation, in spring, with the lowest intervals in autumn (2 ${ }^{\circ} \mathrm{C}$ ) of difference between maximum and minimum and the highest in winter $\left(5^{\circ} \mathrm{C}\right)$, considering the variation scales of This parameter with respect to the other physicochemicals, is estimated to be lower from the temporal point of view, especially because it is located in a tropical latitude. Compared with other authors, similarity is estimated in the Bermúdez-Reyes et al., ${ }^{15-17}$ It should be noted that within the few differences these are justifiable to interannuality, time and sampling sites. Likewise, artificial lakes of the same latitude as that of Chapultepec, Muro-Cruz ${ }^{18}$ registered an oscillation between 17.2 to $18.9{ }^{\circ} \mathrm{C}$; Guzman-Trejo ${ }^{19}$ in Lake Tezozomoc estimated a variation between 15.5 (February) to $24.2{ }^{\circ} \mathrm{C}$ (April), the results obtained in the present study are similar in their annual march, as a result of its location at the same latitude. Given that conductivity is a conservative factor, the differences are associated with local pluvial, subterranean or springs input as in the Oriente Quarry and precipitation-evaporation rates that range between 400 to $500 \mu \mathrm{S} \mathrm{cm}-1$, in previous records such as the carried out by other authors estimated a variation within the interval determined in the Oriente González-Martínez et al.,, ${ }^{20,16,21}$ Comparatively with other artificial water bodies, higher conductivity intervals have been recorded, as an example the study by GuzmánTrejo $^{19}$ in Lake Tezozomoc, where a variation of between 194 to $2142 \mu \mathrm{S} \mathrm{cm}-1$ was determined, as a consequence of the discharges of treated waters and at the rate they are produced, A condition similar to that referred to by Jiménez-Contreras ${ }^{22}$ in some channels of Lake Xochimilco with levels that fluctuated between 300 and $1100 \mu \mathrm{S} \mathrm{cm}-1$ between 2005 and 2006. According to Esteves ${ }^{23}$ the fluctuations in conductivity as a conservative parameter are result of the climatic variations between the rainy and dry seasons, added to the anthropogenic contributions and their speed and inadequate treatment. In the case of the variation in the Oriente Quarry, it is subject mainly to seasonality (drought and rains), to the extraction of water for the irrigation of the gardens and the services of the personnel and the changes in the infiltration through the Cerro del Adjusco according to the time of year (communication from Biol. Francisco Martínez, head of the Oriente Quarry).

The concentration and the percentage of saturation of dissolved oxygen registered heterogeneous conditions without association with the times of the year; However, since it is a non-conservative gas, its solubility between the atmosphere and the water surface depends on biological factors such as phytoplankton activity (photosynthesisrespiration), mainly, whose distribution can be in patches and consequently on the time of day and in the second instance of geomorphology; complex situation observed in the Oriente Quarry. Given the above, this gas can range from aerated conditions, supersaturation, to hypoxia, as determined between 3.0 to $13.9 \mathrm{mg} /$ L (31 to $177 \%$ sat. OD). Comparatively, Bermúdez-Reyes ${ }^{15}$ estimated a condition of supersaturation (131 to $227 \%$ sat. OD) and GonzálezGutiérrez $^{16}$ observed a variation between 4.2 to $18.7 \mathrm{mg} / \mathrm{L}$ (49 to $219 \%$ sat. DO), the lower percentage of which corresponds to hypoxic conditions. Santiago-Lima ${ }^{24}$ estimated a saturation percentage, which ranged from 89 to $227 \%$ sat. OD; Lugo-Vázquez et al. ${ }^{21}$ calculated between 75 to $267 \%$ sat result of the influence of the physicochemical and biological factors, already mentioned. Compared to other artificial bodies of water they have been recorded from anoxic to supersaturated conditions; as, for example, Lake Chapultepec where Muro-Cruz ${ }^{18}$ quantified from 9.5 to $13.09 \mathrm{mg} / \mathrm{L}$ (113 to $156 \%$ sat. OD) that indicated good conditions; however, Domínguez-Pascual ${ }^{25}$ in the Zumpango lagoon registered a concentration between 0.5 to $8 \mathrm{mg} / \mathrm{L}$ corresponding to 15 and $120 \%$ sat. OD, between the bottom and the surface respectively, which has reflected both suitable and inappropriate conditions for aquatic life Martínez-Córdoba ${ }^{26}$ Based on the above, the East Quarry, as an artificial reservoir, has presented conditions similar to natural water bodies, ranging from hypoxia to supersaturation, based on the Boyd and Lichtkoppler classification, ${ }^{27}$ resulting not only of physicochemical and biological factors that regulate oxygen concentration; but this gas also responds to local, anthropogenic and recreational factors.

The $\mathrm{pH}$ ranged in general from a slightly acidic, neutral to alkaline environment, except for one month in two places: at the mouth of the Canal and at the Spring, where acidic conditions of up to 5.5 units were recorded as a result of anthropogenic influence and the possible dissolution of the andesitic volcanic rock (Personal communication Dr. A. Márquez); in the rest of the sites, the variation in $\mathrm{pH}$ influenced by photosynthesis and respiration of phytoplankton is considered. This parameter presents a daily variation of between 7.5 and 9.5 under normal conditions in semi-closed water bodies of high primary production of Lanza Espino and Hernández Pulido ${ }^{28}$ Previous studies on the East Quarry, point out that the $\mathrm{pH}$ range can range from slightly acidic to alkaline in response to primary production and respiration; this variation can be exemplified with the studies of Hernández-Martínez et al. ${ }^{29}$ who estimated from 7.1 to 7.8 , LugoVázquez et al. ${ }^{16,21}$ between 6.3 to 9.9 , due to nocturnal respiration and diurnal photosynthesis. In other artificial water bodies, such as Lake Chapultepec Muro-Cruz ${ }^{18}$ reported averages tending to alkalinity of 9.5 and for its part Namihira-Santillán ${ }^{30}$ in the lake of Parque Huayamilpas between 7.8 to 9.3 , attributing this to high primary production due to nocturnal respiration and daytime photosynthesis. In other artificial water bodies, such as Lake Chapultepec Muro- 
$\mathrm{Cruz}^{18}$ reported averages tending to alkalinity of 9.5 and for its part Namihira-Santillán ${ }^{30}$ in the lake of Parque Huayamilpas between 7.8 to 9.3 , attributing this to high primary production due to nocturnal respiration and daytime photosynthesis. In other artificial water bodies, such as Lake Chapultepec Muro-Cruz ${ }^{18}$ reported averages tending to alkalinity of 9.5 and for its part Namihira-Santillán ${ }^{30}$ in the lake of Parque Huayamilpas between 7.8 to 9.3, attributing this to high primary production.

The orthophosphates present in both artificial and natural continental aquatic ecosystems can have different origins with variation in space and time, therefore the concentration intervals of nutrients (phosphorus and nitrogen compounds) can have similar or different scales. Both aquatic ecosystems are influenced by rock and river basin; also of the Esteves anthropogenic discharges. ${ }^{23}$ Another factor that influences the variation in these two types of aquatic systems are the biological processes of photosynthesis and respiration, which have a determining influence on the space-time variation. The concentration of orthophosphates varied in space and time with contents similar to other bodies of water; Nevertheless. A punctual maximum level was recorded in the runoff from Cerro del Ajusco, Spring of $83.87 \mu \mathrm{M}$ that exceeds the average registered in all samplings ( $25 \mu \mathrm{M}$ indicating eutrophication) and can be explained by the discharges from the houses settled on the slopes of the river. Cerro and infiltrate through the cracks, although a methodological error is not ruled out. The contents determined in the present study were similar to those registered eleven years ago by Hernández-Martínez et al. ${ }^{29}$ with levels from 21.6 to $22.4 \mu \mathrm{M}$; and more recently by GonzálezGutiérrez in 2015 (16) who quantified contents between 2 and 56 $\mu \mathrm{M}$, the latter estimated in the Spring; even Lugo-Vázquez et al. ${ }^{21}$ quantified from 0.6 to $10 \mu \mathrm{M}$; The previous differences may be the result of phytoplanktonic blooms that assimilate the orthophosphate that is distributed in patches and without correspondence of the samplings with other studies Lugo-Vázquez et al..$^{21}$ infers a eutrophic condition due to the constant contribution by the activities of the sports center that is located within the so-called Cantera Oriente, on the other hand Ponce-Márquez et $\mathrm{a}^{131}$ refers to the high concentrations found in the spring water makes one suspect that it comes from the defrosts of the Ajusco, however, the adjacent urban discharges should be mentioned. The concentration ranges are similar to those recorded in other artificial water bodies; for example, in the Alameda Oriente where Montaño-Salazar ${ }^{32}$ determined between 10 to $50 \mu \mathrm{M}$ or in the natural aquatic system called the Ramal de Tláhuac by Castro-Juárez ${ }^{33}$

In both artificial and natural continental bodies of water, dissolved ammonia comes from the decomposition of proteins of animal and vegetable origin, a process known as ammonification of Lanza Espino and Hernández Pulido ${ }^{34}$ This nitrogenous nutrient fluctuates widely spatially and temporally in relation to the level of productivity and in part to the contamination of organic matter Reid and Wood. ${ }^{35}$ In the Oriente Quarry, ammonium registered a temporal variation with the maximums in June and October above $20 \mu \mathrm{M}$, the rest of the samples showed heterogeneous concentrations, even in some specific cases both less than or greater than $20 \mu \mathrm{M}$. For their part, Novelo et al. ${ }^{17}$ in a single sample a wide interval between 6 and $46 \mu \mathrm{M}$, with the maximum in the South section. Compared to other urban natural water bodies, Like the Tláhuac Branch, Castro-Juárez ${ }^{33}$ estimated an interval of 8 to $93 \mu \mathrm{M}$, concluding that there is contamination of anthropic origin. The ammonium concentrations determined in the Oriente Quarry are characteristic of water with little contamination of organic matter (NH4 $+<50 \mu \mathrm{M})$ according to what was indicated by de la Lanza Espino; NOM Ecological Flow (NMX-AA-159-SCFI-2012) $(10 ; 36)$ for lentic water bodies. Therefore, it is estimated that the
Oriente Quarry is under acceptable conditions for this nutrient. 50 $\mu \mathrm{M})$ according to what was indicated by de la Lanza Espino; NOM Ecological Flow (NMX-AA-159-SCFI-2012) $(10 ; 36)$ for lentic water bodies. Therefore, it is estimated that the Oriente Quarry is under acceptable conditions for this nutrient. $50 \mu \mathrm{M}$ ) according to what was indicated by de la Lanza Espino; NOM Ecological Flow (NMXAA-159-SCFI-2012) $(10 ; 36)$ for lentic water bodies. Therefore, it is estimated that the Oriente Quarry is under acceptable conditions for this nutrient.

Nitrite (NO2-) is the intermediate phase of the oxidation of nitrogenous inorganic compounds and is found in low quantities in natural and artificial continental systems Esteves. ${ }^{23}$ In the Oriente Quarry, this nutrient registered a spatiotemporal variation of 0.14 to 4.0 $\mu \mathrm{M}$, an interval considered normal to slightly high. Other artificial water bodies such as Alameda Oriente Montaño-Salazar ${ }^{32}$ determined a variation between 0.3 to $3 \mu \mathrm{M}$; similar to the East Quarry; However, very high contents have been recorded, such as those reported by Luna-Pabello and Aburto-Castañeda ${ }^{37}$ in the Lago del Bosque de San Juan de Aragón, with an interval between 0.14 and $44 \mu \mathrm{M}$, that the maximum could be the result of methodological errors or because said body receives wastewater treated with a deficient purification process.

Nitrate (NO3) along with ammonium are the main sources of nitrogen for primary producers in water bodies. This ion, according to Reid and Wood ${ }^{35}$ is found in concentrations of less than $21 \mu \mathrm{M}$ in uncontaminated fresh water bodies throughout the world; however, this concentration may be higher in continental water bodies such as those registered in some water bodies as stated by MartínezCórdoba. ${ }^{26}$ Its concentration varies with the pluvial and fluvial contributions, and decomposition of autochthonous and alien organic matter Santiago-Lima. ${ }^{24}$ In the Oriente Quarry, a wide variation was estimated between 10.71 to $57.14 \mu \mathrm{M}$. Studies previously carried out at the Oriente Quarry in the same year were different. However, some authors such as Hernández-Martínez et al..$^{29}$ estimated a spatial variation between 22.6 and $41 \mu \mathrm{M}$, similar to the present study; There are extraordinary concentrations such as those quantified by Novelo et al. ${ }^{17}$ who determined a broader interval from 135.3 to $657.1 \mu \mathrm{M}$, even González-Gutiérrez ${ }^{16}$ estimated a higher variation of between 171.5 to $871.1 \mu \mathrm{M}$ in 2013, these levels can be attributed methodological errors. Compared to other aquatic systems. Compared with other aquatic systems Enríquez-García et al..$^{38}$ determined nitrate concentrations in Lake Huetzalin (water body considered within Xochimilco) similar to those of the present study ( 42 to $73 \mu \mathrm{M}$ ); similar to what was reported by Domínguez-Pascual ${ }^{25}$ who quantified concentrations between 10 and $64 \mu \mathrm{M}$ artificial bodies in Lake Zumpango considered as eutrophied. Based on the above, the content of this nutrient in the Oriente Quarry is classified as a eutrophic system with contamination from various runoffs of anthropogenic origin Lugo-Vázquez et al. ${ }^{21}$ the influence of the bathrooms in the sports area, septic tanks, discharges in cracks in urban settlements on the slopes of Cerro del Ajusco.

The phosphorus concentration in water bodies is widely used as a direct indicator of trophic status, given its importance as a limiting factor for Esteves primary producers. ${ }^{23}$ In the Oriente Quarry, total phosphorus registered a wide variation interval from 35 to $80 \mu \mathrm{M}$ with a heterogeneous variation, including concentrations higher than 100 $\mu \mathrm{M}$ in all the sampling sites in April 2018 characterized by being a month of drought according to the Climate reports in Mexico April 2018 (Climate Report in Mexico April 2018 (CONAGUA, National Meteorological Service Year 8 No 4$)^{39}$ with the possible concentration of total phosphorus. Hernández-Martínez et al. ${ }^{29}$ estimated an interval between 40 to $47 \mu \mathrm{M}$ more than a decade ago; recently SantiagoLima $^{24}$ reported an interval of 4 to $18 \mu \mathrm{M}$ in 2013 , later when Lugo- 
Vázquez et al. ${ }^{21}$ determined a range from 2 to $40 \mu \mathrm{M}$. Bernal-Brooks and Alcocer ${ }^{40}$ refer for the epicontinental bodies of Mexico a variation between 0.25 to $64 \mu \mathrm{M}$, similar to the average of the Oriente Quarry except for the month of April where contents were reached 1.5 times that registered in the Oriente Quarry. Alcocer et al. ${ }^{41}$ determined an interval in the Old Lake of Chapultepec between 18 to $70 \mu \mathrm{M}$; Domíngue ${ }^{25}$ in Lake Zumpango estimated a variation of 16 to $80 \mu \mathrm{M}$. Based on Vollenweider et al. ${ }^{8,42}$ defined that concentrations above 3 $\mu \mathrm{M}$ of total phosphorus, the Oriente Quarry would be categorized as a hypertrophic body of water.

For the estimation of the trophic state the total nitrogen content is required, Ebina et al. ${ }^{43}$ The concentration of total nitrogen in the Oriente Quarry registered visible differences both spatial and temporal with the lowest average concentrations in August and October 2017 with 354 and $452 \mu \mathrm{M}$ compared to the maximums in the other samplings in which the months of maximum drought stand out. February with $836 \mu \mathrm{M}$ and April $735 \mu \mathrm{M}$, from 2018. Hernández-Martínez et al. ${ }^{29}$ in a single sample quantified lower levels in 2006 with 45.7 to 82.7 $\mu \mathrm{M}$, which meant a lower content of organic matter to remineralize it. However, ten years later Santiago-Lima ${ }^{24}$ determined an interval of 445 to $665 \mu \mathrm{M}$, similar to what was quantified in the present study. Compared to other artificial aquatic systems, such as the channels of Lake Xochimilco, where Jiménez-Contreras ${ }^{22}$ recorded an interval of 32 to $96 \mu \mathrm{M}$; For his part, López ${ }^{44}$ recorded contents between 279 and $732 \mu \mathrm{M}$ in the Tezozomoc recreational lake. Total nitrogen in the Oriente Quarry presents concentrations indicative of a hypertrophic condition (greater than $140 \mu \mathrm{M}$ ) according to Yang et $a .^{42}$ The concentration of some photosynthetic pigments by volume is used as a usable estimate for primary production considering its low precision, especially for chlorophyll "a" Margalef ${ }^{45}$ and despite being an index of primary production it gives an approximate idea when this pigment is transformed with the formula of Ryther and Yentsch. ${ }^{11}$

Chlorophyll " $a$ " concentrations in the Oriente Quarry registered wide spatio-temporal variation, highlighting the highest contents in April and the lowest in October; However, within these two months of sampling, minimums were recorded in April between 3 and $12 \mathrm{mg}$ $/ \mathrm{m}^{3}$ in the Spring, as well as specific contents greater than $500 \mathrm{mg} /$ $\mathrm{m}^{3}$ in August and February. The determined interval resembles the fluctuation observed by Lugo-Vázquez et al..$^{21}$ from 2 to $468 \mathrm{mg} / \mathrm{m}^{3}$ and by González-Gutiérrez ${ }^{16}$ from 1 to $278 \mathrm{mg} / \mathrm{m}^{3}$. Alcocer et al. ${ }^{41}$ quantified similar concentrations of 275 to $700 \mathrm{mg} / \mathrm{m}^{3}$ of chlorophyll in the Viejo de Chapultepec lake; Enríquez-García ${ }^{38}$ registered a variation from 143 to $696 \mathrm{mg} / \mathrm{m} 3$ in Lake Huetzalin, with maximums higher than those registered in the Oriente Quarry. The wide variation observed in the Oriente Quarry may be due to the distribution in patches of phytoplankton caused by the Álvarez-Borrego and Nájera de Muñoz wind ${ }^{46}$ and even by local and specific physicochemical factors. The relationship between phosphorus content and chlorophyll is discussed by Wetzel et al., ${ }^{47,8}$

Chemical Oxygen Demand (COD) is an estimate of the amount of dissolved organic matter, which is normally low in freshwater, below $20 \mathrm{mg} / \mathrm{L}$. Thorn Spear. ${ }^{10}$ In the Oriente Quarry, a heterogeneous variation interval of 25 to $92 \mathrm{mg} / \mathrm{L}$ was determined, above the normal maximum indicated by the same author for Mexican lakes and reservoirs. In Lake Chapultepec, Muro-Cruz ${ }^{18}$ recorded average values higher than those of the present study from 81 to $141 \mathrm{mg} / \mathrm{L}$, attributing this to the contribution of non-native organic matter and sewage to this system. In the case of the Oriente Quarry, the maximum contents can be attributed to the rest of the vegetation in different degrees of decomposition. Hardness can be classified as permanent, where sulfates predominate and temporary, characterized by Margalef carbonate, ${ }^{45}$ which in both cases can vary in concentration depending on the season; It can be expressed as $\mathrm{CaCO}_{3}$ hardness and is associated with alkalinity. The degree of hardness has been categorized in the following concentrations according to Sawyer and McCarthy ${ }^{48}$ : 0-75 $\mathrm{mg} / \mathrm{L}$ soft water, $75-150 \mathrm{mg} / \mathrm{L}$ moderately hard, 150 to $300 \mathrm{mg} / \mathrm{L}$ hard water and $>300 \mathrm{mg} / \mathrm{L}$ very hard waters. In the case of the Oriente Quarry, and according to the records obtained, the water is considered moderately hard to hard, including the waters that are provided in the Spring, according to the records of Lanza Espino. ${ }^{10}$ In a point estimate, Hernández-Martínez et al. ${ }^{29}$ determined levels lower than $75 \mathrm{mg} / \mathrm{L}$ in the Oriente Quarry, which are classified as soft to moderately hard waters. The foregoing indicates that the Oriente Quarry has a temporal spatial variation due to concentration or dilution effects.

\section{Statistical analysis}

Statistical analyzes are a tool that allows inferring the existence of patterns in all types of data; however, its use and interpretation in limnological studies must be based on a chemical, physical and biological basis. The PERMANOVA nonparametric statistical test is used to compare data groups and determine statistically significant differences between the dispersion of Anderson measured values.$^{49}$ According to the PERMANOVA test, there are statistically significant differences between the site called Manantial and the rest of the Quarry, due to differences in the concentrations of chlorophyll "a", total phosphorus and orthophosphates. Likewise, the test found that there are significant differences between the North section and the South section, but not between the North and Center, and Center and South sections. The results of the test indicate a spatial regionalization in the East Quarry that can be attributed to differences and geomorphological similarities between each of the sections, with the Spring being the one with the greatest differences compared to adjacent lakes. The PERMANOVA test carried out to measure the temporal variation between seasons of the year determined significant differences between autumn (October) and all other seasons, which can be attributed to the characteristic rains of this time of year.

It should be noted that the spatial and temporal variability of the physicochemical parameters, both conservative and non-conservative, is wide and subject to particular conditions present during sampling at a particular site. The results of the statistical tests presented should be considered as a support in the determination of patterns and not as evidence of these Margalef. ${ }^{45}$ The trophic state of an aquatic system results from the interaction of external factors and various internal processes involving biotic and abiotic factors Carpenter and Pace..$^{50}$ The concentrations of total phosphorus, total nitrogen and chlorophyll "a" of the East Quarry define a hypetrophic condition; In this regard, indices have been created that use these parameters with the intention of classifying aquatic systems in a clear way. One of the indices used to estimate the trophic state of the East Quarry is the one proposed by Carlson ${ }^{2}$ whose calculated values less than 30 correspond to an oligotrophic state, between 30 and 60 to a mesotrophic state, from 60 to 90 eutrophic and more than 90 hypereutrophic. According to the estimates made.

The aquatic system of the East Quarry is hypereutrophic all year round in all the sampling sites of the North, Center and South sections, as a result of its high content of the aforementioned parameters; In support of the trophic state, low transparency was observed due to the high algal densities. The Spring registered a lower trophic level given the lower chlorophyll intervals, despite this a eutrophic level was classified as a consequence of the high concentrations of total phosphorus. It should be noted that in April and February, indices above the limit proposed by Carlson ${ }^{2}$ were calculated in all sections 
except the Spring given the maximums for total phosphorus and chlorophyll "a". Santiago-Lima ${ }^{4}$ estimated the trophic state using the same method and in the same sections determined a eutrophic state and in the Manantial a mesotrophic state. The difference with the present study was due to an increase of more than $20 \%$ in the amount of chlorophyll "a". The trophic classification of lakes usually contains four categories or classes, oligotrophic, mesotrophic, eutrophic and hypertrophic (Table 6).

Table $\mathbf{6}$ The following table shows the correspondence between the value of the indices and the trophic classification

\begin{tabular}{lllll}
\hline Item & Chl & $\mathbf{P}$ & SD & $\begin{array}{l}\text { Trophic } \\
\text { classification }\end{array}$ \\
\hline$<30-40$ & $0-2.6$ & $0-12$ & $>8-4$ & Oligotrophic \\
$40-50$ & $2.6-20$ & $24-\mathrm{Dec}$ & $2-\mathrm{Apr}$ & Mesotrophic \\
$50-70$ & $20-56$ & $24-96$ & $2-0.5$ & Eutrophic \\
$70-100+$ & $56-155+$ & $96-384+$ & $0.5-<0.25$ & Hypertrophic \\
\hline
\end{tabular}

\section{Conclusion}

Artificial water bodies are fed by rain, by natural and man-made river diversions (dams and banks), by discharges of various kinds, among others, by contributions of water from the terrestrial area that show similarities as a result. and differences in water bodies, which also vary in space and time as a consequence of the climate of tropical latitudes. An example of the above variability is Lake Cantera Oriente located in the Mexican highlands. Seasonal variations decrease year after year as a result of population growth with poor anthropogenic management in which the multiple and diverse services with possible variations of climate change are taken into account; The foregoing impacts on the aquatic environmental aspects (physicochemical, geomorphological and biological). This reservoir has been studied intermittently and the present study includes some years ago a study to determine the degree of trophy (eutrophication up to hyper-eutrophication), fundamentally generated by the increase in total phosphorus and chlorophyll "a" both from human settlements and its peripheral discharges. It should be noted that the distribution of the physicochemical and biological parameters do not present a homogeneous distribution but in patches due to the wind and hydrogeomorphological dynamics. Therefore, any study to be followed in this body of water is recommended to take into consideration previous studies to better understand its trend and conservation.

\section{Acknowledgments}

None.

\section{Conflicts of interest}

The autor declares there is no conflcit of interest.

\section{References}

1. National Research Council, Academy of Scientific Research AC, National Academy of Engineering, AC. The Water Supply in Mexico City, improving sustainability. 1999. p. 114

2. Carlson RE. Trophic state index for lakes. Limnol. Oceanogr. 1977;22(2):361-369.

3. González-Gutiérrez S. Seasonal variation of monogont rotifers (Rotifera) in the littoral zone of the Cantera Oriente water bodies (Mexico, DF) during 2013-2014. Master's Thesis. Institute of Marine Sciences and Limnology. National Autonomous University of Mexico. 2015. p. 75.
4. Santiago-Lima AM. Comparative study of zooplankton (rotifers and cladocerans) in the water bodies of Cantera Oriente, $D F$ and its relationship with the trophic state. Professional thesis, Biology, Iztacala School of Higher Studies, UNAM. 2016. p. 60.

5. Lot A. Illustrated guide to the East Quarry. Environmental characterization and biological inventory. Coordination of Scientific Research, Executive Secretariat of the Pedregal de San Ángel Ecological Reserve of Ciudad Universitaria. Mexico. National Autonomous University of Mexico. 2007. p. 108.

6. Lot A, Cano-Santana Z. Biodiversity of the Pedregal de San Angel ecosystem. Commemorative Book of the $25^{\text {th }}$ anniversary of the Ciudad Universitaria Ecological Reserve (1983-2008). Pedregal de San Ángel Ecological Reserve. Coordination of Scientific Research, UNAM., México, DF. 2009. p. 538

7. APHA, AWWA, WPCF. Standard Methods for the examination of water and wastewater. $20^{\text {th }}$ edn. American Public Health Association, Washington, DC, USA. 1998. p. 1103.

8. Vollenweider RA, Giovanardi F, Montanari G, et al. Characterization of the trophic conditions of marine coastal Waters with special reference to the NW Adriatic Sea: a proposal for a trophic scale, turbidity and generalized water quality index. Environmetrics. 19898;9(3):329-357.

9. Hammer $\varnothing$, Harper DA, Ryan PD. PAST: Paleontological statistics software package for education and data analysis. Electronic paleontology. 2001;4(1):9.

10. de la Lanza-Espino, G. Protocol for water quality sampling in endorheic and exorheic rivers, and in wetlands for the application of the Ecological Flow Standard (NMX-AA-159-SCFI-2012). Version 1.0. June 2014. National Program for Water Reserves. 2014. p. 54.

11. Ryther JH, Yentsch CS. The estimation of phytoplankton production in the ocean from chlorophyll and light data. Woods Hole Ocean Inst. WHM Cont. No. 902. 1957. p. 120.

12. Lara-Lara JR, Álvarez-Borrego S. Annual cycle of chlorophylls and primary organic production in Bahía San Quintín, BC Ciencias Marinas. 1975;2(1): 77-97.

13. Muciño-Márquez RE, Aguirre-León A, Figueroa-Torrez MG. Evaluation of the trophic state in the Pom-Atasta and Palizada del Este river lagoon systems, Campeche, Mexico. Hydrobiological. 2017;27(3):281-291.

14. García E. Modifications to the Köppen climate classification system. $5^{\text {th }}$ edn. Institute of Geography, UNAM. 2004. p. 75.

15. Bermúdez-Reyes Y. Diversity of the Cladocera Order (Crustacea: Branchiopoda; Phyllopoda) from the pools of the Pedregal de San Angel Ecological Reserve, Ciudad Universitaria, Mexico. Professional thesis, Biology. Science Faculty. National Autonomous University of Mexico. 2010. p. 76.

16. González-Gutiérrez S. Seasonal variation of monogont rotifers (Rotifera) in the littoral zone of the Cantera Oriente water bodies (Mexico, 48 DF) during 2013-2014. Master's Thesis. Institute of Marine Sciences and Limnology. National Autonomous University of Mexico. 2015. p. 67.

17. Novelo E, Ponce E, Ramírez R, et al. Illustrated Guide to the East Quarry. Environmental characterization and biological inventory. Coordination of Scientific Research. Executive Secretariat of the Pedregal de San Ángel Ecological Reserve, UNAM, Mexico. 2007. p. 15-44.

18. Muro-Cruz G. Contribution to the knowledge of the distribution and abundance of cladocerans in the three lakes of Chapultepec. Professional thesis, Biology. Iztacala Faculty of Higher Studies. National Autonomous University of Mexico. 1994. p. 56.

19. Guzmán-Trejo O. Effect of nutrients on the growth and composition of planktonic rotifers from Lake Tezozomoc, Mexico DF. Professional thesis, Biology. Iztacala Faculty of Higher Studies. National Autonomous University of Mexico. 2012. p. 68. 
20. González-Martínez M, Ramírez-Marcial N, Camacho-Cruz A, et al. Forest restoration in indigenous territories of Chiapas: ecological models and action strategies. Boletín de la Sociedad Botánica de México, 80 (Supplement), 2007. p. 11-23.

21. Lugo-Vázquez A, Sánchez-Rodríguez MR, Morlán-Mejía J, et al. Ciliates and trophic state: A study of five adjacent urban ponds in Mexico City. Journal of Enviromental Biology. 2017;38:1161-1169.

22. Jiménez-Contreras CJ. Diversity and densities of Monogonto rotifers in some channels of Lake Xochimilco. Bachelor's Thesis. Iztacala Faculty of Higher Studies. National Autonomous University of Mexico. 2007. p. 69

23. Esteves FA. Fundamentals of Limnology. Interciencia. $2^{\text {nd }}$ edn. Brazil. 1998. p. 226.

24. Santiago-Lima AM. Comparative study of zooplankton (rotifers and cladocerans) in the water bodies of Cantera Oriente, DF and its relationship with the trophic state. Professional thesis, Biology, Iztacala School of Higher Studies, UNAM. 2016. p. 60.

25. Domínguez-Pascual IE. Study of the diversity of zooplankton and phytoplankton of the Zumpango lagoon (state of Mexico) for its use in biomanipulation. Professional thesis, Biology. Iztacala Faculty of Higher Studies. National Autonomous University of Mexico. 2006. p. 68.

26. Martínez-Córdoba LR. Ecology of aquaculture systems. $2^{\text {nd }}$ edn. AGT Editorial, Mexico. 1998. p. 200.

27. Boyd Claude E, Lichtkoppler F. Water Quality Management in Pond Fish Culture. International Center for Aquaculture Agricultural Experiment Station Research and Development. Series No. 22, 1979. p. 32.

28. de la Lanza Espino G, Hernández Pulido S. Variation of water quality in La Ciénega de Tláhuac, CIENCIA ergo-sum, 26 (3) 2019. p. 1-20.

29. Hernández-Martínez O, Quiroz A, Ramírez-García P. Lake landscape: ecology of aquatic vegetation. In: A Lot editor. Illustrated Guide to the East Quarry: environmental characterization and biological inventory. Mexico: Coordination of Scientific Research, Executive Secretariat of the Pedregal de San Ángel Ecological Reserve of Ciudad Universitaria, UNAM. 2007. p. 45-59.

30. Namihira-Santillán PE. Evaluation of the sanitary quality of Lake Huayamilpas, DF Professional thesis, Hydrobiology. Division of Biological and Health Sciences. Metropolitan Autonomous University, Iztapalapa Unit. 2002. p. 55.

31. Ponce-Márquez ME, Ramírez-Rodríguez R, Ramírez Vázquez M. Algas de la Cantera Oriente. Pedregal de San Angel Ecological Reserve. Field and laboratory guide. $1^{\text {st }}$ edn. Science presses. Mexico. 2019. p. 152.

32. Montaño-Salazar I. Hydrobiological aspects in two locks of the artificial lake of the Alameda Oriente park. Professional thesis, Biology. Faculty of Higher Studies Zaragoza. National Autonomous University of Mexico. $2010 ; 58$.

33. Castro-Juárez M. Physicochemical and bacteriological analysis of the water quality Ramal Tláhuac 1991-1992. Professional thesis, Biology. Science Faculty. National Autonomous University of Mexico. 2000. p. 79
34. de la Lanza-Espino G, Hernández-Pulido S. Environment, Biology, Society, Management and Legislation of Mexican Coastal Systems. Universidad Michoacana Nicolaita de Hidalgo (INIREMA), WWFGonzalo Río Arronte Foundation-PyV. 2011. p. 491.

35. Reid GK, Wood RD. Ecology of inland waters and estuaries. $2^{\text {nd }}$ edn. D. Van Nostrand Company, New York, USA. 1976. p. 223.

36. Mexican Standard NMX-AA-159-SCFI. The Establishing the Procedure for the Determination of Ecological Flow in Hydrological Basins. Microsoft Word-NMX-AA-159-SCFI-2012.docx. 2012. p. 10.

37. Luna-Pabello VM, Aburto-Castañeda S. System of artificial wetlands to control eutrophication of the San Juan de Aragón forest lake. Specialized Magazine in Chemical-Biological Sciences. 2014;17(1):32-55.

38. Enríquez-García E, Nandini S, Sarma SSS. Seasonal dynamics of zooplankton in Lake Huetzalin, Xochimilco (Mexico City, Mexico) Limnological. 2009;39:283-291.

39. Conagua, National Meteorological Service. General Coordination of the National Meteorological Service Management of Meteorology and Climatology Sub-management of Medium and Long-Term Forecast No 4. 2018. p. 55 .

40. Alcocer J, Bernal-Brooks FW. Limnology in Mexico. Hydrobiology. 2020;644:15-68.

41. Alcocer J, Kato E, Robles E, et al. Preliminary study of the effect of dredging on the trophic state of the old lake of Chapultepec. Environmental pollution. 1988;4:43-56.

42. Yang $\mathrm{X}, \mathrm{Wu} \mathrm{X}, \mathrm{Hao} \mathrm{H}$, et al. Mechanisms and assessment of water eutrophication. J Zheijang Univ Sci B. 2008;9(3):197-209.

43. Ebina J, Tsutsui T, Shirai T. Simultaneous determination of total nitrogen and total phosphorus in water using peroxodisulfate oxidation. Water research. 1983;17(12):1721-1726.

44. López SG. Experimental study of the impact of Poecilia reticulata (Guppy) and environmental conditions on rotifer assemblages in Lake Urbano Tezozomoc. Bachelor's Thesis. Iztacala Faculty of Higher Studies. National Autonomous University of Mexico. 2012. p. 75

45. Margalef LR. Limnology. Omega. Barcelona, Spain. 1983. p. 1010.

46. Álvarez-Borrego S, Nájera-Muñoz S. Phytoplankton time series in two coastal lagoons of Baja California. Marine Sciences. 1979;6(1):75-88.

47. Wetzel RG. Limnology. Lake and River Ecosystem. $3^{\text {rd }}$ Edn. Academic press. New York, USA. 2001. p. 330.

48. Sawyer C, McCarthy P. Chemical and sanitary engineering. McGraw Hill. New York, USA. 1967. p. 3-5.

49. Anderson MJ. Permanova: a FORTRAN computer program for permutational multivariate analysis of variance. Department of Statistics, University of Auckland, New Zealand. 2005. p. 245.

50. Carpenter SR, Pace ML. Dystrophy and eutrophy in lake ecosystems: implications of fluctuating inputs. Oikos. 1977;78:3-14. 